\title{
Inspiration for delegation
}

\begin{abstract}
Amelia Bray, Chairman BDPMA, shares her practice management wisdom in regard to delegating tasks.
\end{abstract}

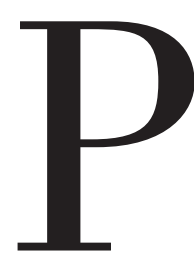

ractice principal may be the fancier title but everybody knows it's us practice managers who really run the business. Staffing, premises, legislation, health and safety, finance, equipment, stock control, customer service, computer systems... compare those responsibilities to simply evacuating a root canal. And practice managers don't have someone to hand them their tools and make them cups of coffee. Feet up thanks to a cancelled appointment - I wish! An endless supply of gloves so your hands don't get dirty - yes please!

Okay, so I wouldn't swap my job for all the tea in the teapot but that doesn't mean I wouldn't welcome some help now and again. To get it, I need to embrace the ' $d$ '-word delegation. I think it was Ronald Reagan who said: 'Surround yourself with the best people you can find, delegate authority, and don't interfere.'

I've done the first bit but 'the action of giving one's work or responsibilities to someone else' (as the Oxford English Dictionary puts it) still comes hard. Or it did.

A serious session of self-analysis one evening - fuelled by a glass of wine and a complete absence of anything decent on the telly had me thinking. What would unblock my delegating logjam? I wasn't precious about the practice - running it is a team effort, not the sole preserve of me, me, me. And I wasn't concerned that somebody else would do things better - I could always claim it was my inspired delegation that was the catalyst.

No, my main fear was that I'd give the wrong task to the wrong person. They would be unable to cope and their confidence would be dented. I'd have a lot of repair work to do. Meanwhile, a team member better suited to the task would be mystified and possibly upset that I'd not chosen them instead.

I needed to find out what my staff were capable of without letting them know I was doing it. The way to achieve this was to discover more about what each of them did away from the practice. I knew their ages and whether they were married but I realised I knew nothing about their hobbies or interests.

Nursing a slight headache the next morning, I began asking leading questions: 'What will you be doing this weekend, then Nicky?'; 'I'll be baking cakes this evening, how about you Vicky?'; 'Who is your favourite author Becky?'

I got strange looks at first but they soon opened up - people do generally like talking about what they enjoy and what interests them.

Scuttling back to my office, I made notes and after a few days I'd accumulated quite a list of outside interests.

One nurse was a Brown Owl in charge of a dozen Brownies. She was used to organising instructional evenings and even taking them away on camps. I mentally put her down for arranging and facilitating team meetings.

A receptionist was fascinated by local history and seemingly spent hours at the local library researching and then writing up her notes in a yet to be published book. She would be just right for sorting out our stock control system, I thought.

My team included a yachtswoman, a town councillor and an amateur dramatist. I was

\section{'I wouldn't swap} my job for all the tea in the teapot but that doesn't mean I wouldn't welcome some help now and again.'

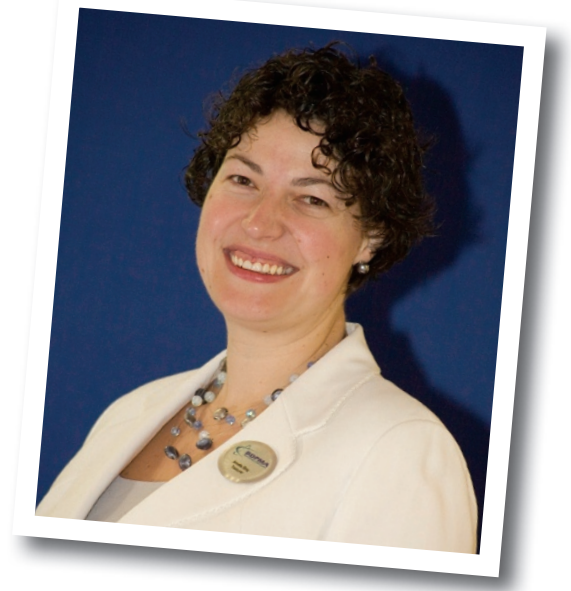

able to think of jobs for each of them. Only the Morris dancer stumped me.

At the next team meeting, I announced the delegated tasks only to be met by silence and glum faces. Later, I stumbled in on a lunch break conversation where I was clearly not the flavour of the month.

It was the Morris dancer, to whom I'd been unable to delegate a task, who came to my rescue. She collared me in the car park and explained the sullen mood of the staff. It seems they had each chosen pastimes which bore no resemblance to their work. The contrast was part of the attraction.

I began to appreciate where I'd gone wrong. Here was I, a dental practice manager and outside of work what did I do? It certainly wasn't practice management related.

The next day, I called another team meeting at which I said very little. Instead, I put a list of the tasks I wished to delegate on a flipchart and left them to it. When I returned ten minutes later, they'd allocated each task by some method or other and everybody was happy. Those that had something quite unfamiliar to them reasoned that finding out about it would be both challenging and interesting.

And the Morris dancer? Well, she's done a really good job in the storeroom and has identified the different shelves with coloured hankies.

I must finish by saying that this sort of practice management experience is what gets shared by BDPMA members at our meetings, workshops and networks. When we ask members what one thing they rate most beneficial about BDPMA membership, they often reply: 'Networking.'

If you want to join the BDPMA network (there are many other benefits too) go to www. bdpma.org.uk or telephone Denise Simpson at BDPMA HQ on 01452886364 . Or you could delegate somebody to do it... 